\title{
Evaluasi Implementasi Kurikulum 2013 di SDN Talabiu Kabupaten Bima NTB
}

\author{
Sri Lastuti ${ }^{1}$, Anisah $^{1{ }^{1 *}}$ \\ ${ }^{1}$ STKIP Taman Siswa Bima \\ *anisahmathedu@gmail.com
}

\section{Artikel Info}

Tanggal Publikasi

2019-06-30

Kata Kunci
Evaluasi
Kurikulum 2013
Implementasi.

\section{Abstrak}

Tujuan dari penelitian ini adalah untuk mengetahui implementasi kurikulum 2013 di SDN Talabiu kabupaten Bima yang terdiri dari implementasi perencanaan, pelaksanaan proses pembelajaran, evaluasi pembelajaran dan kendala-kendala yang dihadapi guru dalam implementasi kurikulum 2013. Metode evaluasi yang digunakan adalah model Countenan Stake yang membagi komponen kurikulum dalam matrik observasi dan matrik pertimbangan meliputi tahap pendahuluan (antecedent), proses (transaction), dan hasil (outcomes). Pengumpulan data dilakukan dengan wawancara, observasi dan dokumentasi. Teknik analisis data dengan menggunakan Mixed Method Data hasil wawancara dianalisis dengan menggunakan metode deskriptif kualitatif, sedangkan data hasil observasi dianalisis dengan menggunakan metode deskriptif kuantitatif sesuai kriteria yang telah ditentukan. Hasil dari penelitian ini menunjukan bahwa kesiapan sekolah yang dilihat dari ketersediaan Buku, kesiapan dokumen RPP dan kesiapan guru sebagai tenaga pengajar tergolong dalam kategori baik (telah sesuai dengan standar yang telah ditetapkan oleh pemerintah). Pelaksanaan proses pembelajaran termasuk dalam kategori baik. Implementasi penilaian autentik dan respon siswa dalam proses pembelajaran sudah menunjukkan respon yang positif. Meski demikian implementasi kurikulum 2013 pada ke-Tiga aspek tersebut harus selalu ditingkatkan agar ketercapaian termasuk pada kriteria sangat Baik. Kendala yang dihadapi guru dalam implementasi kurikulum 2013 sangat beragam mulai dari permasalahan terkait persiapan pembelajaran, permasalahan dalam proses pembelajaran hingga pada aspek penilaian otentik.

\section{PENDAHULUAN}

Upaya telah dilakukan pemerintah untuk meningkatkan mutu pendidikan, salah satunya dengan melakukan penyesuaian kurikulum sesuai dengan tuntutan zaman. Berbagai kurikulum yang telah diterapkan di Indonesia yaitu kurikulum 1947, kurikulum 1952, kurikulum 1964, kurikulum 1968, 1974, kurikulum 1975, kurikulum 1984, kurikulum 1994, kurikulum 2004, kurikulum 2006 dan kurikulum 2013.

Kurikulum 2013 merupakan kurikulum yang sedang diterapkan saat ini. Kurikulum 2013 mulai diterapkan di Indonesia sejak 15 Juli 2013 oleh kementrian pendidikan dan kebudayaan di 6.326 skolah. Dengan berpedoman pada peraturan menteri pendidikan dan kebudayaan Republik Indonesia Nomor 81A tahun 2013 tentang implementasi kurikulum. Sri Budiani dkk (2016:45). Kurikulum 2013 mentik beratkan pada pendekatan saintifik, penilaian otentik dan tematik integratif. Aspek penilaian pada iplementasi kurikulum tersebut yaitu aspek pengetahuan, keterampilan, sikap dan perilaku, yang harapannya dapat menghasilkan lulusan yang kreatif, inovatif, berdaya saing sesuai tuntutan zaman.

Permendikbud 2013 (Dimas Qondias dkk. 2018: 65) menuangkan tentang kurikulum 2013 dirancang dengan karakteristik sebagai berikut: 1) Mengembangkan keseimbangan antara pengembangan sikap spiritual dan sosial, rasa ingin tahu, kreativitas, kerja sama dengan kemampuan 
intelektual dan psikomotorik; 2) Sekolah merupakan bagian dari masyarakat yang memberikan pengalaman belajar terencana dimana peserta didik menerapkan apa yang dipelajari di sekolah ke masyarakat dan memanfaatkan masyarakat sebagai sumber belajar; 3) Mengembangkan sikap, pengetahuan, dan keterampilan serta serta diterapkan dalam berbagai situasi di sekolah dan masyarakat; 4) Memberi waktu yang cukup leluasa untuk mengembangkan berbagai sikap, pengetahuan, danketerampilan; 5) Kompetensi dinyatakan dalam bentuk kompetensi inti kelas yang dirinci lebih lanjut dalam kompetensi dasar Mata pelajaran; 6) Kompetensi inti kelas menjadi unsur pengorganisasi (organizing elements) kompetensi dasar, dimana semua kompetensi dasar dan proses pembelajaran dikembangkan untuk mencapai kompetensi yang dinyatakan dalam kompetensi inti; 7) Kompetensi dasar dikembangkan didasarkan pada prinsip akumulatif, saling memperkuat (reinforced) dan memperkaya (enriched) antar mata pelajaran dan jenjang pendidikan.

Diawal pencetusannya kurikulum 2013 tidak semulus yang diharapkan, berbagai pro kontra ikut mewarnai kemunculan kurikulum tersebut. Namun hal tersebut tidak menyurutkan semangat sekolah dalam melaksanakan kurikulum 2013.

Kurikulum 2013 di Kota dan Kabupaten Bima sudah diterapkan oleh sebagian besar sekolah SD/MI, SMP/MTS dan SMA/MA. SDN Talabiu adalah salah satunya sekolah yang telah mengimplementasikan kurikulum tersebut sejak tahun 2015.

SDN Talabiu didirikan pada 31 Desember 1976. Sekolah trsebut terakreditasi B. Kepala sekolah bernama Bapak Ihwan, M.Pd. sekolah tersebut memiliki lokasi yang sangat strategis karena berada di pinggir jalan lintas propinsi kecamatan Woha. Lokasi sekolah berdampingan langsung dengan SDN Inpres Talabiu, meskipun demikian sekolah tersebut tetap dapat menunjukan eksistensinya dengan memiliki 292 siswa aktif yang terdiri dari 161 (siswa perempuan) dan 131 (siswa laki-laki).

Namun untuk mengetahui apakah pelaksanakaan kurikulum tersebut sudah sesuai dengan standar yang ditentukan oleh pemerintah, maka harus dilakukan evaluasi secara menyeluruh, mulai dari persiapan yang terdiri persiapan guru, kesiapan RPP, ketersediaan sarana prasarana, pelaksanaan proses pembelajaran, penilaian, pelayanan terhadap siswa dan masalah-

Masalah yang dihadai guru dalam implementasi kurikulum 2013.

\section{METODE}

Penelitian evaluasi ini dilakukan di SDN Talabiu Kabupaten Bima. Model evaluasi yang dipergunakan yaitu Countanance Stake. Model ini membagi kegiatan evaluasi dalam tahapan pendahuluan (antencedent), proses (transaction) dan hasil (outcomes). Sanders,JR, Worthen, B.R.,\& Fitzpartrick,J.L 1973 (Sri Budiani dkk. 2017: 47).

Hasil observasi akan dibandingkan dengan data standar nasional pendidikan Indonesia yang berkaitan dengan implementasi kurikulum 2013. Sumber Data diperoleh dari hasil wawancara dan dokumentasi dari guru kelas dan kepala sekolah. Wawancara digunakan untuk memperoleh informasi tentang kesiapan guru dalam mengimplementasikan kurikulum 2013, sedangkan observasi dipergunakan untuk memperoleh informasi tentang kondisi sarana prasararana, kesiapan dokumen RPP, proses pembelajaran, instrumen penilaian, respon peserta didik dalam penilaian, pelayanan terhadap siswa dan masalah- masalah yang dihadapi guru dalam implementasi kurikulum 2013.

Metode penelitiana yang dipergunakan adalah Mixed Method untuk memperoleh data yang lebih valid, komprehensif, reliabel dan objektif. Data hasil wawancara dianalisis dengan menggunakan metode deskriptif kualitatif, sedangkan data hasil hasil observasi dianalisis dengan menggunakan metode seskriptif kuantitatif dengan kriteria yang telah ditentukan. 


\section{HASIL DAN PEMBAHASAN}

Adapun hasil evaluasi dalam penelitian ini yaitu Implementasi perencanaan yang terdiri dari kesiapan tenaga guru dan kesiapan RPP yang disajikan pada tabel berikut.

Tabel 1. Kesiapan RPP

\begin{tabular}{llcccc}
\hline \multirow{2}{*}{ No } & \multirow{2}{*}{ Indikator yang dinilai } & \multicolumn{4}{c}{ RPP } \\
\cline { 3 - 6 } & & 1 & 2 & 3 & 4 \\
\hline 1 & Identitas Mata Pelajaran & 4 & 4 & 4 & 4 \\
2 & Perumusan Indikator & 3 & 3 & 3 & 2 \\
3 & Perumusan Tujuan Pembelajaran & 3 & 3 & 3 & 3 \\
4 & Pemilihan Materi Ajar & 4 & 4 & 4 & 4 \\
5 & Pemilihan Sumber Belajar & 3 & 3 & 3 & 3 \\
6 & Pemilihan Media Belajar & 3 & 3 & 3 & 3 \\
7 & Menentukan metode dan Model Pembelajaran & 3 & 3 & 3 & 3 \\
8 & Langkah-langkah kegiatan pembelajaran & 3 & 2 & 3 & 2 \\
9 & Penilaian & 3 & 3 & 3 & 3 \\
\hline Jumlah & 29 & 27 & 29 & 26 \\
\hline Rata-rata skor & 3,2 & 3 & 3,2 & 2,8
\end{tabular}

Adapun RPP yang dimaksud pada tabel tersebut yaitu tema tentang a) indahnya kebersamaan, b) selalu berhemat energi, c) Peduli terhadap mahluk hidup dan d) Berbagai pekerjaan. Berdasarkan data pada tabel 1 tersebut diperoleh informasi bahwa secara umum bahwa kemampuan guru dalam mempersiapkan perncanaan pembelajaran dari item identifikasi mata pelajaran hingga penilaian termasuk dalam kategori baik. Guru memiliki kemampuan yang baik dalam menyusun rencana pembelajaran (RPP) karena sebelumnya telah mengikuti workshop yang diselenggarakan oleh pemerintah yang berkaitan dengan implementasi kurikulum 2013. Ibu Dina Sefriani, S.Pd sudah diberikan file tentang RPP kurikulum 2013 dan tinggal dikembangkan sesuai dengan potensi lokal sekolah. Selain itu guru kelas juga pada tahun 2018 telah menjadi mitra penugsan dosen STKIP Taman Siswa Bima ke sekolah (PDS) sehingga telah memiliki banyak pengalaman dalam merancang RPP yang berbasik kurikulum 2013..

Adapun ketersediaan tenaga pengajar di SDN Talabiu yaitu sebanyak 25 guru dengan rincian Sbb:

Tabel 2 Ketersediaan tenaga penganjar

\begin{tabular}{clcc}
\hline No & \multicolumn{1}{c}{ Nama } & Kualifikasi Akademik & Tugas \\
\hline 1 & Ihwan, M.Pd & S2 & Kepala Sekolah \\
2 & Siti Masmani, S.Pd & S1 & Guru kelas 6B \\
3 & Kamrul S.Pd i & S1 & Guru agama \\
4 & Sri W, S.Pd & S1 & Guru kelas 6A \\
5 & Fatimah S.Pd & S1 & Guru kelas 4A \\
6 & Sri W.SY, S.Pd & S1 & IA \\
8 & Irfan, S.Pd & S1 & Olah raga \\
9 & Aswan S.Pd.i & S1 & Agama \\
10 & Nur Afliani, S.Pd & S1 & 5B \\
11 & Wiwid, S.Pd & S1 & 2A \\
12 & Nur silah, S.Pd & S1 & Pend. 2 \\
13 & Efi, S.Pd & S1 & 4B \\
14 & Dina S., S.Pd & S1 & 5A \\
15 & Alina, S.Pd & S1 & 1B
\end{tabular}




\begin{tabular}{llcc}
16 & Sudirman, S.Pd & S1 & 3A \\
17 & Nurlina, S.Pd & S1 & 3A \\
18 & Adi A, S.Pd & S1 & Olahraga \\
19 & Rosdiana, S.Pd & S1 & Matematika \\
20 & Sri N., S.Pd & S1 & $3 B$ \\
21 & Nursiah, S.Pd & S1 & $5 \mathrm{~A}$ \\
22 & Yulianti, S.Pd & S1 & Matematika \\
23 & Eka H, S.Pd & S1 & $6 \mathrm{~B}$ \\
24 & Adl. Kasir, S.Pd & S1 & Seni \\
25 & Sulastri, S.Pd & S1 & \\
\hline
\end{tabular}

Pada tabel tersebut tampak bahwa secara kualifikasi akademik 100\% guru SDN Talabiu telah memenuhi standar pendidikan untuk mengajar. Seorang guru wajib menempu pendidikan di strata Satu karena Guru adalah ujung tombak penentu keberhasilan siswa. Untuk dapat menjadi guru yang baik minimal seorang guru harus memiliki kompetensi yang diperolehnya selama proses pendidkan yang ditempuhnya maupun dalam proses pengalamannya. Empat kompetensi tersebut yaitu kompetensi pedagogik (cakup pemahaman terkait landasan kependidikan, pemahaman terhadap peserta didik, pengembangan kurikulum/ silabus, perencanaan pembelajaran, pelaksanaan pembelajaran yang mendidik dan dialogis, pemanfaatan teknologi pembelajaran, evaluasi proses dan hasil belajar dan pengembangan peserta didik untuk mengaktualisasikan berbagai kompetensi yang dimiliki)., Kompetensi kepribadian, sosial dan profesional. Dan untuk meningkatkan kemampuan tersebut guru-guru SDN Talabiu diikut sertakan dalam kegiatan pelatihan, seminar maupun workshop. Jumlah guru tersebut telah memnuhu rasio guru yang dibutuhkan pada tiap-tiap kelas. Guru-guru tersebut telah berulang kali diikut sertakan dalam kegiatan pelatihan, worshop baik itu yang berkaitan dengan pelatihan implementasi kurikulum 2013 dari pemerintah, maupun yang dilakukan bersama mitra dalam peningkatan kapasitas guru. Guru-guru SDN Talabiu juga dibekali pelatihan tentang tehnik penyusunan instrumen penilaian berbasis HOTS yang didalamnya mencakup penilaian otentik. Pelatihan dan pendampingan tersebut dilakukan agar seluruh guru mendapat pengetahuan tentang implementasi kurikulum 2013 karena guru yang mendapat penataran dari pemerintah jumlahnya terbatas. Pun jika dalam pelaksanaan pelatihan pendampingan tersebut guru-guru masih bingung dalam hal implementasi kurikulum 2013 maka dilakukan tutor sebaya.

Ketersediaan sarana Prasarana

Tabel 3. Ketersediaan sarana Prasarana.

\begin{tabular}{clccl}
\hline No & Sarana Prasarana & Ketersediaa & Kondisi & Keterangan \\
\hline 1 & Ruangan kelas & $\sqrt{ }$ & Baik & \\
2 & Ruangan kepala sekolah & $\sqrt{ }$ & Baik & Ruangan menyatu \\
3 & Ruangan TU & $\sqrt{ }$ & Baik & \\
4 & Ruangan komputer & $\sqrt{ }$ & Baik & \\
5 & Ruangan UKS & - & - & \\
6 & Laboratorium IPA & - & - & Belum ada \\
7 & LCD & $\sqrt{ }$ & Baik & \\
8 & Lab. Bahasa & - & - & Belum ada \\
9 & Sarana olahraga & $\sqrt{ }$ & & Belum lengkap \\
10 & Sarana ibadah & $\sqrt{ }$ & Baik & \\
11 & Sarana kesenian & $\sqrt{ }$ & & \\
12 & Internet & - & - & Tidak tersedia \\
13 & WC & $\sqrt{ }$ & Baik & \\
14 & Kursi siswa & $\sqrt{ }$ & Baik &
\end{tabular}




\begin{tabular}{lllll}
15 & Meja siswa & $\sqrt{ }$ & Baik & \\
16 & Meja guru & $\sqrt{ }$ & Baik & \\
17 & Kursi guru & $\sqrt{ }$ & Baik & \\
18 & Lemari & $\sqrt{ }$ & Baik & Ada disetiap ruagan \\
19 & Papan mading & $\sqrt{ }$ & & \\
20 & Kipas angin & $\sqrt{ }$ & & Di ruangan guru \\
21 & Papan tulis & $\sqrt{ }$ & Baik & \\
22 & Kantin sekolah & $\sqrt{ }$ & & \\
\hline
\end{tabular}

Berdasarkan tabel 3 terkait sarana pra sarana yang dimiliki SDN Talabiu masih terdapat itemitem yang belum ada, seperti ketersediaan laboratorium bahasa dan laboratorium IPA, wifi dan UKS. Sedangkan untuk sarana olah raga juga belum mewadai. sekolah memiliki halaman yang luas namun potensi lahan tersebut belum dimanfaatkan sepenuhnya untuk dijadikan laboratorium alam sebagai penunjang pembelajaran. Meskipun sarana pra sarana masih kurang namun kepala sekolah dan guru SDN Talabiu mensiasati dengan mengoptimalkan peralatan yang ada disekitar lingkungan sekolah sebagai penunjang proses belajar mengajar. Di SDN Talabiu UKS jika belum tersedia namun untuk kagiatan siswa yang berkaitan dngan UKS disiasasti dengan menunjuk guru sebagai penanggung jawab seperti kegiatan dokter kecil dikoorditor oleh Ibu Wiwid Pratiwi, S.Pd.

\section{Evaluasi Proses Pembelajaran.}

Adapun indikator yang dinilai dalam proses pembelajaran disajikan pada tabel berikut.

Tabel 4 Evaluasi terhadap proses pembelajaran

\begin{tabular}{clc}
\hline No & \multicolumn{1}{c}{ Indikator yang di Nilai } & Skor \\
\hline 1 & Keterampilan membuka pelajaran & 3 \\
2 & Keterampilan menyampaikan materi sesuai tujuan pembelajaran & 3 \\
3 & Keterampilan mengelola kelas & 3 \\
4 & Melaksanakan pembelajaran sesuai dengan RPP yang disusun & 3 \\
5 & Keterampilan memberikan motivasi & 3 \\
6 & Keterampilan berinteraksi dengan siswa & 3 \\
7 & Kterampilan membimbing siswa & 3 \\
8 & Keterampilan menetapkan metode pembelajaran dengan efektif & 3 \\
9 & Keterampilan menggunakan media dan sumber belajar & 4 \\
10 & Keterampilan menutup pelajaran & 3 \\
\hline & $\quad$ Total: & 3.1 \\
\hline
\end{tabular}

Berdasarkan data tersebut nampak bahwa guru telah memiliki keterampilan yang baik dalam mengajar, meskipun demikian guru harus tetap meningkatkan kemampuan pada berbagai indikator tersebut agar pencapain yang diperoleh siswa sesuai dengan ouput yang ditekankan pada implementasi kurikulum 2013.

Dari seluruh indikator yang diamati keterampilan guru dalam dalam menggunakan media dan sumber belajar memperoleh point tertinggi, hal tersebut dikarenakan pada saat observasi di kelas tema tentang bersyukur atas keberagaman materi SBDP guru tengah memanfaatkan limbah yang tidak terpakai untuk diolah menjadi produk kerajinan yang sangat indah yang memiliki nilai seni yang tinggi.

Sementara untuk pelaksanaan saitifik dapat disajikan pada tabel berikut.

Tabel 5 Kegiatan saintific guru

\begin{tabular}{clc}
\hline No & Indikator yang di Nilai & Skor \\
\hline 1 & Pendahuluan & 3 \\
2 & Menanya & 4
\end{tabular}




\begin{tabular}{clc}
3 & Mengamati & 4 \\
4 & Mengumpulkan data/mencoba & 3 \\
5 & Menganalisis & 2 \\
6 & Mengkomunikasikan & 3 \\
7 & Menutup & 3 \\
\hline \multicolumn{2}{c}{ Total } & 22 \\
\hline & Rata-rata & 3.1
\end{tabular}

Berdasarkan data tersebut diperolah bahwa sebagian kegiatan saitifik yang dilakukan oleh guru sudah trlaksana secara baik, namun masih ada juga indikator yang yang harus ditingkatkan seperti menganalisis. Kegiatan-kegiatan seperti penndahuluan, pengumpulan data dan penutup juga dapat ditinkatkan lagi agar lebih sistematis dan akurasi waktu sesuai dengan waktu yang direncanakan.

Selain proses saitific, aspek lain yang diobservasi yaitu terkait pemahaman otentik guru. Pemahaman otentik guru disajikn pada tabel 6 berikut.

Tabel 6 tentang pemahaman otentik guru.

\begin{tabular}{clc}
\hline No & \multicolumn{1}{c}{ Indikator yang di Nilai } & Skor \\
\hline 1 & Konsep dan aplikasi penilaian otentik & 3 \\
2 & Konsep aplikasi penilaian diri & 4 \\
3 & Konsep dan aplikasi ulangan harian & 4 \\
4 & Konsep dan aplikasi penilaian berbasis portofolio & 3 \\
5 & Konsep dan aplikasi ulangan tengah semester & 3 \\
6 & Konsep dan aplikasi ulangan akhir semester & 3 \\
7 & Konsep dan aplikasi ujian tingkat kompetensi & 1 \\
\hline & Total & 22 \\
\hline & Rata-rata
\end{tabular}

Berdasarkan data tersebut diperoleh informasi bahwa guru telah memahami dengan baik terkait aplikasi penilaian otentik, konsep aplikasi penilaian diri, konsep dan aplikasi penilaian ulangan harian, ulangan tengah semestar dan konsep aplikasi penilaian akhir semester. Yang perlu diberikan pemahaman yang berkaitan dengan konsep dan aplikasi tingkat kompetensi karena sekolah belum mengembangkan aplikasi tersebut.

Terkait dengan penggunaan metode dan strategi belajar guru telah mampu memilih metode dan strategi belajar yang sesuai dengan kurikulum 2013. Hanya saja dalam pelaksanaanya terkadang penggunaan metede maupun strategi tersebut kurang berjalan maksimal karena guru maupun siswa yang masih butuh dibiasakan.

\section{Evaluasi Hasil Belajar}

Evaluasi dipergunakan untuk mengukur tingkat capaian peserdidik dari proses pembelajaran yang dilakukan oleh guru. Jenis-jenis evaluasi pembelajaran sangat beraagam yang dapat dipergunakan untuk mengukur kemampuan siswa tersebut dengan mempertimbangkan aspek karakteristik siswa. Indikator seorang guru dapat melakukan proses evaluasi dengan baik ketika ia mampu memahami dengan baik terkait aplikasi penilaian otentik, konsep aplikasi penilaian diri, konsep dan aplikasi penilaian ulangan harian, ulangan tengah semestar dan konsep aplikasi penilaian akhir semester. Yang perlu diberikan pemahaman tambahan yang berkaitan dengan konsep dan aplikasi tingkat kompetensi. Penilaian yang dilakukan guru di SDN Talabiu yaitu dengan memberikan instrument tes maupun yang non tes baik yang berupa penilaian tugas, penilaian lewat kuis, proyek untuk menghasilkan produk, fortofolio dan sebagainya. 


\section{Aktivitas peserta didik}

Pada implementasi kurikulum 2013, guru dituntut untuk dapat memaksimalkan peran siswa. Salah satunya dengan cara memaksimalkan proses saitifik siswa baik itu yang berupa proses bertanya, mengamati, mengumpulkan data, menganalisis hingga dalam mengkomunikasikannya. Di SDN Talabiu untuk memaksimalkan aktivitas siswa, tidak hanya dikembangkan melalui proses belajar mengajar di dalam kelas, tetapi juga dengan kegiatan ekstra kurikuler. Kepala sekolah dan guru-guru SDN talabiu sangat peka dalam mendeteksi minat dan bakat siswa untuk dikembangkan lebih lanjut pada kegiatan ekstra kurikuler dan siswa SDN Talbiu sudah menjuarai bergai bidang kompetisi baik pada tingkat kecamata, Kabupaten, Provinsi hingga nasional.

Adapun kegiatan ekstra kurikuler yang dikembangkan oleh SDN Talabiu yaitu tari, pencak silat, Dakwah keagamaan dan menggambar. Selain itu adapun layanan yang diberikan dalam mengoptimalkan aktivitas siswa yaitu dengan layanan pengayaan kesulitan belajar siswa, layanan komunikasi dengan wali siswa dan untuk menginformasikan dan manyamakan antara visi misi orang tua dengan sekolah dan layanan administrasi.

\section{Kendala yang dihadapi dalam implementasi kurikulum 2013}

Meskipun pada banyak hal terkait implementasi kurikulum 2013 di SDN Talabiu sudah berjalan dengan baik, namun sangat banyak kendala-kendala yang dihadapi guru diawal pelaksanaanya. Adapun berbagai prmasalah tersebut diantaranya: 1) Guru masih membutuhkan banyak pemahaman yang berkaitan dengan pola pendekatan student centred karena seblumnya guru masih dominan dalam proses pembelajaran di kelas; 2) Belum semua mampu mengaplikasikan pendekatan saintifik dalam proses pembelajaran; 3) Seluruh materi harus dikaitkan dalam kehidupan sehari-sehari sehingga guru harus kerja keras untuk untuk memahami hal tersebut; 4) Minat baca siswa yang masih minim; 5) Siswa masih terbiasa menggunakan bahasa Ibu, jadi membutuhkan waktu dalam penyesuaian dalam bahasa Indonesia; 6) Membutuhkan media ajar yang beragam sementara guru-guru SDN talabiu sebagian besar (76\%) berstatus guru sukarela; 7) Sarana penunjang seperti lingkungan sekitar sekolah, laboratorium dan lain-lain yang belum mendukung untuk dilakukan proses pembelajaran di luar kelas; 8) Guru terbiasa melakukan penilaian pada aspek kognitif saja; 9) Penguasaan bidang administrasi yang masih kurang; 10) Pemahaman guru yang masih lemah terkait implementasi kurikulum 2013; 11) Kemampuan dalam bidang IT guru yang masih kurang; 12) Pemahaman akan instrumn HOTS yang masih kurang; 13) Pelatihan tentang penyusunan instrumen yang berkaitan dengan kurikulum 2013 yang masih terbatas; 14) Dll.

\section{KESIMPULAN}

Berdasarkan hasil penelitian dan pembahasan maka penelitian ini dapat disimpulkan bahwa kesiapan sekolah yang dilihat dari ketersediaan Buku, kesiapan dokumen RPP dan kesiapan guru sebagai tenaga pengajar tergolong dalam kategori baik (telah sesuai dengan standar yang telah ditetapkan oleh pemerintah). Pelaksanaan proses pembelajaran termasuk dalam kategori baik. Implementasi penilaian autentik dan respon siswa dalam proses pembelajaran sudah menunjukkan respon yang positif. Meski demikian implementasi kurikulum 2013 pada ke-Tiga aspek tersebut harus selalu ditingkatkan agar ketercapaian termasuk pada kriteria sangat Baik. Kendala yang dihadapi guru dalam implementasi kurikulum 2013 sangat beragam mulai dari permasalahan terkait persiapan pembelajaran, permasalahan dalam proses pembelajaran hingga pada aspek penilaian otentik. Berdasarkan permadalahan tersebut maka dalam mengimplementasikan kurikulum 2013 hendaknya hndaknya pemerintah maupun pejabat terkait terus mendorong agar sekolah-sekolah mampu memenuhi standar yang telah ditetapkan agar implementasi kurikulum 2013 dapat mnghasilkan output sesuai dengan yang diharapkan oleh pemerintah. 


\section{Daftar Pustaka}

Asep Jihad \& Abdul Haris. (2010). Evaluasi pembelajaran. Yogyakarta: Multi Pressindo.

Dimas Qondias, Pelipus Wunggo Kaka dan Maria Infiolata. 2018. studi evaluasi kurikulum 2013 tingkat sekolah dasar di wilayah timur indonesia. Jurnal Pendidikan Dasar PerKhasa Volume 4, Nomor 1, April 2018. https://repository.usd.ac.id/7229/2/132222211 full.pdf. Diakses pada tanggal 5 januari 2019

Djemari Mardapi. (2008). Teknik penyusunan instrumen tes dan non tes. Yogyakarta: Mitra Cendekia Press.

Dwi Faquziyyatul Laely. 2016. Evaluasi pelaksanaan kurikulum 2013 di SDN Petompon 01 Kecamatan gajah mungkur Kota semarang. https://lib.unnes.ac.id/24548/1/1102411008.pdf. Artikel.

E. Mulyasa. (2005). Standar kompetensi dan sertifikasi guru. Bandung: PT Remaja Rosdakarya.

Fitzpatrick, J.L., Sanders, J.R \& Worthen, B.R. (2011). Program evaluation: Alternative approaches and practical guidelines. New Jersey: Perarson Education Inc.

Indri Noviatmi. 2015. Evaluasi Implementasi Kurikulum 2013 Kelas I \& IV SD di Kabupaten magelang tahun pelajaran 2014/2015. http://eprints.uny.ac.id/24022/7/tesis-andri-noviatmi13712259001.pdf

Sanders, R. \& Sullins, D.C. (2006). Evaluating school programs: An educator's guide. California: Corwin Press.

Sri Budiani, Sudarmin \& Rodia Syamwil. 2017. Evaluasi Implementasi Kurikulum 2013 di Sekolah Pelaksana Mandiri. Innovative Journal of Curriculum and Educational Technology IJCET 6 (1) (2017) : 45 - 57.https://journal. Unnes.ac.id/sju/index.php/ujet/article/view/15998. Diakses pada tanggal 5 januari 2019.

Sri Lastuti \& Amat Jaedun. 2013. Evaluasai Pelaksanaan Program S1 Pendidikan Guru Sekolah Dasar (PGSD) di Unit Program Belajar Jarak Jauh (UPBJJ) Universitas Terbuka (UT) Daerah Istimewa Yogyakarta (DIY) tahun 2013. Jurnal Kependidikan (Volume 44, Nomor 1 Mei 2014, ISSN. 0125-992X). https://journal.uny.ac.id/index.php/ik/article/view/2190 